\title{
The Effectiveness Of Additional Papain Enzyme In Artificial Diets On Protein Hydrolysis And Protease Enzyme Activity, White Snapper Larva (Lates calcarifer, Bloch 1790)
}

\author{
Rasdi $^{1}$, Gunarto Latama ${ }^{2}$, Haryati Tandipayuk ${ }^{3}$ \\ ${ }^{1}$ Masters Program, Postgraduate School, Hasanuddin University, Makassar, Indonesia \\ ${ }^{2}$ Faculty of Marine Sciences and Fisheries, Hasanuddin University, Makassar, Indonesia \\ Correspondence Author Email : rasdibdp14@gmail.com \\ DOI: 10.29322/IJSRP.11.12.2021.p12007 \\ http://dx.doi.org/10.29322/IJSRP.11.12.2021.p12007
}

\begin{abstract}
The use of natural diet in rearing barramundi larvae is less effective, so it needs to be limited as early as possible by using artificial diet. To make it easier for larvae to digest artificial diet, exogenous enzymes were added to the artificial diet. This study aims to determine the dose of papain enzyme and the age of the white snapper larvae which resulted in the best degree of protein hydrolysis and protease enzyme activity. Completely Randomized Design (CRD) was used to evaluate the effect of papain enzyme dose on the degree of protein hydrolysis, with four treatments $(0 \%, 1.5 \%, 3 \%$, and $4.5 \%)$ and 3 replications. A factorial pattern with a completely randomized design was used to determine the papain enzyme dose and larval age on the activity of the protease enzyme. The first factor was the dose of papain enzyme $(0 \%, 1.5 \%, 3 \%$, and $4.5 \%)$ while the second factor was the age of the white snapper larvae (14 days, 17 days and 20 days). The results showed that the difference in papain enzyme doses had a significant effect $(\mathrm{P}<0.05)$ on the degree of hydrolysis of diet protein with the best dose of $4.5 \%$, which was $50.30 \%$. The enzyme activity showed that the papain enzyme dose of $4.5 \%$ papain was the highest and had a significant difference $(\mathrm{P}<0.05)$ with other treatments. While the age treatment obtained the best results at the age of 17 larvae $(0.55 \mathrm{U} / \mathrm{g}$ larvae/minute). Differences in papain enzyme dose and larval age of barramundi showed significantly different results $(\mathrm{P}<0.05)$ but the interaction between the two was not significantly different $(\mathrm{P}>0.05)$. Based on the degree of protein hydrolysis of the papain enzyme and the activity of the protease enzyme, white snapper larvae can be fed predigest diet using a 4.5\% papain enzyme dose at 17 days of age.
\end{abstract}

Keywords: protease enzyme activity, degree of protein hydrolysis, papain enzyme, barramundi larvae

\section{INTRODUCTION}

White snapper (Lates calcarifer, Bloch 1790) is one of the aquaculture commodities that has high economic value, because it is in great demand by local and export markets. As an export commodity. The success of the nursery in producing quality seeds is influenced by various aspects, one of which is the diet used. White snapper hatcheries are still relying on natural food, both phytoplankton (Nanochloropsis and tetraselmis) and zooplankton (rotifera and artemia) while the use of artificial diet is used when the larvae are close to harvest, at the age of 20-25 days. However, the use of natural diet in hatchery activities is somewhat less effective due to several factors, namely in the culture process, natural diet is very susceptible to environmental changes and is easily contaminated by pathogenic bacteria that can harm organisms that consume it (Haryati, 2017). In addition, the use of natural diet requires a large container in the culture process so that it will affect the productivity of the hatchery. Therefore, the nursery needs to limit the use of natural diet as early as possible with the use of artificial diet that is in accordance with the needs of white snapper larvae.

The potential use of artificial diet in barramundi hatcheries is quite potential where the artificial diet nutrition can be adjusted to the needs of barramundi larvae. Hardianti et al, (2016) studied the provision of artificial diet with different compositions on white snapper larval aged 30 days and showed positive results on the growth and survival. The main obstacle faced in the effort to substitute artificial diet is the incomplete function of the digestive system in early stage larvae so that enzyme production is still not sufficient to

This publication is licensed under Creative Commons Attribution CC BY. 

ISSN 2250-3153

digest nutrients in the form of complex molecules contained in artificial diet (Rimandi, 2015). So that the application of artificial diet in rearing barramundi larvae requires special treatment that can simplify the nutrients in the diet, by predigest.

Predigest is a simplification of nutrients in diet to be simpler, so that it can be absorbed easily by white snapper larvae. The application of predigest diet has been widely studied by previous researchers using the papain enzyme, Amalia et al. (2013), studied the best dose of papain enzyme in African catfish (C. gariepinus) larvae where from their research the best papain enzyme dose was $2.25 \%$. Hamzah (2015) conducted a study on the effectiveness of adding papain enzyme to artificial diet on the survival and growth of star pomfret (Tracinotus blochii, Lacepede 1801) larvae which in his research showed that the addition of papain enzyme $4 \%$ at the age of 12 and 15 days in artificial diet of fish larvae star pomfret has been shown to have an effect on protease enzyme activity, survival and daily growth. Haryati (2018) studied the effect of artificial diet predigest using papain enzyme on the degree of protein hydrolysis and protease enzyme activity of mud crab larvae (Scylla olivacea) in zoea 2 and 3 where it was found that with the use of papain enzyme $4.5 \%$ mud crab larvae began to develop fed on zoea 2. However, the use of predigest diet with papain enzyme in the rearing of barramundi larvae has never been done.

\section{METHODS}

This research was conducted from August to September 2020 at the Takalar Brackish Water Cultivation Fisheries Center (BPBAP). Analysis of the Hydraulic Degree of Protein and Dissolved Protein was carried out at the Animal Food Chemistry Laboratory, Department of Nutrition and Animal Diet, Faculty of Animal Science, Hasanuddin University, Makassar. while the Analysis of Protease Enzyme Activity was carried out at the Nutrition Laboratory of the Research Institute for Brackish Water Aquaculture and Fisheries Extension (BRPBAP3) Maros.

The test animals used in this study were white snapper larvae that were 1 day old, stocked into the research container and kept until the 30th day using test diet. The containers used in this study were 36 green plastic basins with a capacity of $45 \mathrm{~L}$ and filled with $20 \mathrm{~L}$ of water. The white snapper larvae used in this study came from hatching eggs in BPBAP Takalar which were hatched in the research container.

The enzyme used in this research is papain enzyme with the brand Newzime which is produced by the BBBAP Jepara. The container used in this study was 36 green plastic basins with a capacity of $45 \mathrm{~L}$ and filled with $20 \mathrm{~L}$ of water. The method of preparation and addition of the papain enzyme to the test diet was: first, papain enzyme powder (according to the treatment dose) was dissolved into $10 \mathrm{ml}$ of distilled water, the solution was vortexed and allowed to stand for 10-15 minutes, then the enzyme was sprayed into $100 \mathrm{~g}$ of artificial diet using a $50 \mathrm{~mL}$ sprayer. then the diet is incubated for 60 minutes (Hasan, 2000). The incubated diet is ready to be given to the test animals.

The test diet used in this study was the commercial diet used by BPBAP Takalar. The feeding scheme during the study can be seen in Figure 1 below:

\section{Larval Age (days)}

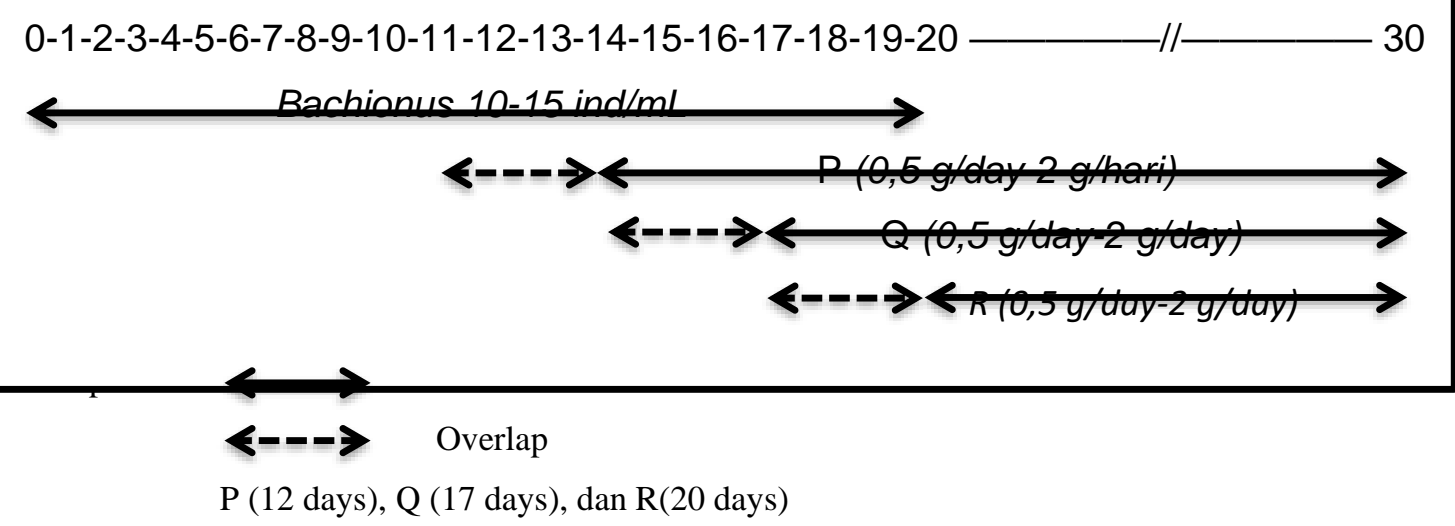

This publication is licensed under Creative Commons Attribution CC BY. 
The study was designed in a factorial pattern with a completely randomized design (CRD). There are 2 factors, the first factor is the dose of papain enzyme (A) and the second factor is the time of feeding predigested with papain enzyme (D) each given 3 replications.

1. The papain $(\mathrm{A})$ enzyme dose is:

$$
\begin{aligned}
& \mathrm{A}(0)=(0 \%) \\
& \mathrm{B}(1)=(1,5 \%) \\
& \mathrm{C}(2)=(3 \%) \\
& \mathrm{D}(3)=(4,5 \%)
\end{aligned}
$$

2. Predigest feeding time (D) is:

D14 = giving predigest diet to 14 days old larvae

D17 = giving predigest diet to 17 days old larvae

D20 = giving predigest diet to 20 days old larvae

Parameters observed in this study include the degree of protein hydrolysis and protease enzyme activity:

\section{Degree of Protein Hydrolysis}

The diet that has been added to the papain enzyme is analyzed for the degree of protein hydrolysis by conducting a proximate test of diet based on the dose of the papain enzyme tested, including those not given the papain enzyme (Control). The degree of hydrolysis of diet protein is calculated by following equation:

$$
D H P=\frac{P_{o}-P_{t}}{P_{o}} \times 100
$$

Description $\quad$ DHP $=$ Degree of Protein Hydrolysis

Po $\quad=$ Protein content of diet at the beginning

$\mathrm{Pt} \quad=$ Protein content of diet at time $\mathrm{t}$

Protease Enzyme Activity

The activity of the protease enzyme is calculated according to the following equation:

$$
U=\left(\frac{A c t-A b l}{A s t-A b l}\right) \times \frac{P}{T}
$$

Description: $\quad \mathrm{U}=$ Unit of protease enzyme activity $/ \mathrm{kg}$ fish $/$ minute

Act $=$ Sample absorption value

Abl = Blank absorption value

Ast = Standard absorption value

$\mathrm{P} \quad=$ Dilution factor

$\mathrm{T} \quad=$ incubation time in minutes

\section{Data Analysis}

To determine the effect of papain enzyme dose and feeding age of predigest white snapper larvae on the degree of protein hydrolysis and protease enzyme activity were analyzed using analysis of variance (ANOVA), if the results were significant $(\mathrm{P}<0.05)$, then proceed with the $\mathrm{W}$-Tukey test to determine the dose which the best and the right age for predigest feeding on barramundi larvae.

\section{Degree of Protein Hydrolysis}

\section{RESULTS}

The degree of protein hydrolysis of white snapper larvae diet predigested with papain enzymes can be seen in table 1 below:

Table 1. Average degree of protein hydrolysis of barramundi larvae diet predigested with papain enzyme 


\begin{tabular}{cccc}
\hline Treatment & Average $(\%) \pm$ SD \\
\hline A & 41,99 & $\pm 0,45^{\mathrm{d}}$ \\
B & 44,63 & \pm & $0,83^{\mathrm{c}}$ \\
C & 47,30 & \pm & $0,39^{\mathrm{b}}$ \\
D & 50,30 & \pm & $0,56^{\mathrm{a}}$ \\
\hline
\end{tabular}

Note: Different superscript letters in the same column indicate significant differences $(\mathrm{P}<0.05)$ between treatments

Based on the results of data analysis obtained the average value of the degree of hydrolysis of diet protein in table 1 , it is known that the value of the degree of hydrolysis of diet protein ranges from $41.99 \%-50.30 \%$ with the lowest value obtained in treatment A ( $0 \%$ dose) and the highest in treatment D (4.5\%. dose). The results of analysis of variance (ANOVA) showed that the dose of papain enzyme had a very significant effect $(\mathrm{P}<0.01)$ on the degree of hydrolysis of diet protein. Furthermore, the results of the further analysis of the W-Tuckey test showed that the degree of hydrolysis of diet protein was significantly different $(\mathrm{P}<0.05)$ in all treatments.

The activity of protease enzymes in barramundi larvae fed with different doses of papain enzyme and at different ages can be seen in table 2 below:

Table 2. Average activity of the protease enzyme in barramundi larvae fed with different doses of papain enzyme and larval age.

\begin{tabular}{lcc}
\hline & Treatment & Enzyme activity $(\mathrm{U}$ enzyme/g larva/min) \\
\hline Dose (\%): & 0 & $0,34 \pm 0,02^{\mathrm{d}}$ \\
& 1,5 & $0,44 \pm 0,03^{\mathrm{c}}$ \\
& 3 & $0,62 \pm 0,02^{\mathrm{b}}$ \\
& 4,5 & $0,72 \pm 0,02^{\mathrm{a}}$ \\
\hline Age (days) : & 14 & $0,52 \pm 0,16^{\mathrm{b}}$ \\
& 17 & $0,55 \pm 0,16^{\mathrm{a}}$ \\
& 20 & $0,53 \pm 0,17^{\mathrm{ab}}$ \\
\hline Note: Different superscript letters in the same column indicate significant differences $(\mathrm{P}<0.05)$ between treatments
\end{tabular}

Note: Different superscript letters in the same column indicate significant differences $(\mathrm{P}<0.05)$ between treatments

Based on the average value of the protease enzyme activity of white snapper larvae in table 2 above, it shows that the value of the protease enzyme activity at the papain enzyme dose treatment ranged from $0.72 \mathrm{U}$ enzyme/g larvae/minute $-0.34 \mathrm{U}$ enzyme/g larva/minute. The results of the analysis of variance (ANOVA) showed that the dose of papain enzyme had a very significant effect $(\mathrm{P}<0.01)$ on the activity of the protease enzyme. Furthermore, the results of the further W-Tuckey test showed that the activity of the protease enzyme in white snapper larvae was significantly different $(\mathrm{P}>0.05)$ in all treatments.

In the treatment of barramundi larvae, from the table above the average activity of the protease enzyme, it can be seen that the protease enzyme activity values ranged from $0.52 \mathrm{U}$ of enzyme/g larvae/minute to $0.55 \mathrm{U}$ of enzyme/g larvae/minute. Where the results of analysis of variance (ANOVA) showed that the difference in the age of the white snapper larvae had a significant effect $(\mathrm{P}>0.05)$ on the activity of the protease enzyme. Furthermore, the results of the further W-Tuckey test showed that the activity of the protease enzyme at the age of 17 days was not significantly different $(\mathrm{P}>0.05)$ with the treatment at the age of 20 days, but it was very significantly different $(\mathrm{P}>0.01)$ with the treatment at the age of 14 days., while between treatments aged 20 days and 14 days, the results were not significantly different $(\mathrm{P}>0.05)$.

\section{DISCUSSION}

This study showed that the highest degree of protein hydrolysis was obtained in treatment D with a papain enzyme dose of $4.5 \%$, indicating a protein hydrolysis degree of $50.30 \%$. The high degree of hydrolysis of diet protein obtained in the treatment of $4.5 \%$ papain enzyme dose because the dose can hydrolyze diet protein well. In the early stages of the hydrolysis process, the enzyme will be absorbed into the suspension of the meat particles, then the peptide bond will be broken simultaneously (Hamzah, 2015). In the process of hydrolysis of diet protein, papain enzymes act as a catalyst in accelerating the simplification of nutrients in diet from

This publication is licensed under Creative Commons Attribution CC BY.

http://dx.doi.org/10.29322/IJSRP.11.12.2021.p12007

WWW.ijsrp.org 
complex compounds to simpler compounds so that they are more easily absorbed by white snapper larvae which have an immature digestive system.

The value of the low degree of hydrolysis was obtained at a dose of $0 \%$ and $1.5 \%$ papain enzyme, this was because the enzyme dose was not sufficient to hydrolyze the existing substrate. The degree of protein hydrolysis is influenced by several factors, namely the enzyme dose, hydrolysis time, and the enzymes used (Haryati et al, 2018). Kurniawan's research (2012) on the hydrolysis process of squid ink protein using the papain enzyme resulted in the degree of hydrolysis between $1.69 \%-34.51 \%$, with the smallest hydrolysis degree value found in the P0 treatment ( $0 \%$ enzyme concentration) of $1.69 \%$ and the highest degree of hydrolysis was found in the P2 treatment (2\% enzyme concentration) which was $34.51 \%$. Meanwhile, Haryati (2018) investigated the hydrolysis of artificial diet with papain enzymes in mud crab (Scylla olivacea) larvae in zoea 2 and 3 phases resulting in the degree of protein hydrolysis in JP0 and JP1. JP0 and JP1 are types of commercially made diet used in the form of powder, JP0 is given from zoea stage 1 while JP1 is given at zoea stage 3 . The results showed the highest value at doses of $3 \%$ and $4.5 \%$ with the value of the degree of hydrolysis of JP0 19,753 respectively. \% and $22.890 \%$, while in JP1 they were $18.707 \%$ and $20.430 \%$ respectively and the lowest was obtained at $0 \%$ and $1.5 \%$ papain enzyme doses. Protein hydrolysis is the process of breaking the covalent bonds that link the amino acids that make proteins. In the hydrolysis process the covalent bonds between amino acid molecules will be broken to produce free amino acids. The degree of protein hydrolysis is influenced by several factors, namely enzyme concentration, hydrolysis duration, and the enzymes used. Low degree of protein hydrolysis at $0.0 \%$ and $1.5 \%$ enzyme doses occurred because the enzyme concentration was not sufficient to hydrolyze the substrate.

The dose treatment showed that the higher the papain enzyme dose (treatment D with a dose of $4.5 \%$ papain enzyme) used in predicting the diet, the higher the protease enzyme activity produced. This is due to the activity of protease enzymes in larvae aged 14 , 17 and 20 days. In this treatment, the predigested diet without the papain enzyme resulted in no trigger for enzyme activity in hydrolyzing diet protein. In contrast to the treatment using the papain enzyme, which had a higher enzyme activity, this was due to the activity of the protease enzyme in larvae aged 14, 17 and 20 days, diet that was predigested with the enzyme papain at a concentration of $4.5 \%$ which then played a role in triggering more optimal enzyme activity in hydrolyze diet protein. This is in line with the opinion of Haryati, et al. (2018); Amalia, et al. (2013); Hasan (2000) that the presence of enzymes in artificial diet can help and speed up the digestive process so that enough nutrients can be available for the growth and survival of fish. The more enzymes added to the diet, it will produce more protein which is hydrolyzed into amino acids, so it will increase the digestibility of the fish to the diet. in larvae fed natural food.

The papain enzyme dose given to the artificial diet at a dose of $4.5 \%$ showed optimal results in hydrolyzing the compounds of the artificial diet into simpler ones. This is in accordance with what was stated by Taqwdasbriliani (2013), that the less the addition of the papain enzyme in artificial diet, the less amino acids produced so that the diet given cannot be utilized properly by the larvae, on the contrary the higher the protein is broken down into acid. amino acids, the more is absorbed by the larva's body.

The results of research by Walford et al. (1993) on barramundi larvae showed that the protease enzyme was high in 17-dayold larvae so that they could begin to digest the artificial diet given and were also supported by the digestive system of white snapper larvae at that age. This research was continued and it was found that with the addition of papain enzymes into artificial diet, it could speed up the time of artificial diets on white snapper larvae from 17 days to 14 days. Based on Figure 2 above, it shows that the higher the papain enzyme dose added to the artificial diet, the higher the protease enzyme activity in white snapper larvae.

The use of papain enzymes to hydrolyze artificial diet for fish larvae showed positive results in accelerating the artificial dieting time for larvae. This has been proven by several previous studies such as that conducted by Hamzah et al (2015) showing that artificial diet predigest using papain enzyme at a dose of $4 \%$ is able to speed up the artificial feeding time for star pomfret (Tracinotus blochii) larvae to 12 days, where in Putri's research (2015) said that without giving predigest diet, artificial diet on star pomfret larvae could be given at the age of 18 days. Similar results were obtained from a study conducted by Haryati et al (2018) on the mangrove crab species (Scylla olivacea) showing that predigesting artificial diet for larvae using the enzyme papain 4.5\% was able to speed up the artificial feeding time for mud crab larvae, namely at stadia zoea 2 , where in a previous study conducted by Haryati et al (2014) on mud crab larvae showed that protease, lipase and -amylase enzymes began to be produced at zoea 3 and at that stage it was suspected that new artificial diet could be given. Then further research by Haryati et al (2015) on mangrove crab (Scylla olivacea) larvae showed that protease, lipase and -amylase enzymes were given artificial diet to zoea 2 were still low.

\section{CONCLUSION}

This publication is licensed under Creative Commons Attribution CC BY.

http://dx.doi.org/10.29322/IJSRP.11.12.2021.p12007

WWW.ijsrp.org 
The conclusion of this study is that the degree of protein hydrolysis of the papain enzyme that can be used to hydrolyze diet is $4.5 \%$. Meanwhile, the protease enzyme activity was given predigest diet using a 4.5\% papain enzyme dose at 17 days of larval age.

\section{REFERENCES}

Amalia, R., Subandiyono and A. Endang. 2013. Effect of Papain Use on Diet Protein Utilization Rate and Growth of Dumbo Catfish (Clarias garipenus). Volume 2 (1). Page 136-143.

Aslamyah, S. 2006. Use of Digestive Tract Microflora as Probiotics to Increase Growth and Survival of Milkfish (Chanos-chanos Forskall). Dissertation. Bogor Agricultural University Graduate School. Bogor.

Fadli, J. sunaryo and djunaedi A. 2013. Provision of Papain Enzyme in Commercial Diet on Growth and Diet of Tiger Grouper (Epinephelus fuscoguttatus). Journal of Marine Research. Volume 2 (3). pp. 50-70.

Hamzah H. 2015. The effectiveness of adding papain enzyme to artificial diet on the survival and growth of star pomfret (Trochinotus blochii Lacepede 1801) larvae. UNHAS Postgraduate Program Thesis, 53 Pages.

Hardianti Q, Rusliadi and Mulyadi. 2016. Effect Of Feeding Made With Different Composition On Growth and Survival Seeds Of Barramundi (Lates calcarifer, Bloch). Faculty of Fisheries and Marine Sciences. University of Riau

Haryati, E. Saade and Mirna. 2017. Effect of Lactobacillus sp. on Artificial Diet Against Digestive Enzyme Activity of Milkfish Larvae (Chanos chanos Forskal). Proceedings of the Annual Seminar on Fisheries and Marine Sciences VI Annual Seminar of Fisheries and Marine Science VI. Center for Disaster Mitigation and Coastal Rehabilitation Studies, Undip.

Haryati, Y. Fujaya \& E. Saade, 2018. Effect of predigest artificial diet using papain enzyme on the degree of protein hydrolyses and protease enzyme activity of mud crab (Scylla olivacea) larvae at zoea 2 and 3 stages. Aquaculture Indonesia Journal, 19(2): 76-82.

Haryati, Fujaya Y, Zainuddin, S. Aslamyah, Saade E. 2014. Development of digestive enzyme activity of mud crab (Scylla sp.) from zoea to megalopa stage in relation to the ability to utilize artificial diet. Indonesian Journal of Aquaculture. Vol. 15(1):35 41.

Haryati, Fujaya Y, Anugrah. 2015. Effect of alternating natural diet with artificial diet on the digestive enzyme activity of mud crab (Scylla olivacea). Proceedings of the XII National Seminar on Fisheries and Marine Affairs, volume I of Aquaculture, pages: $137-144$.

Hasan, O.D.S. 2000. Effect of Papain Enzyme in Artificial Diet on Protein Utilization and Seed Growth of Gouramy (Osphronemus gouramy lac.). Thesis Bogor Agricultural University, Bogor. 57 pp.

Kurniawan, Susi Lestari, Siti Hanggita R.J. 2012. Hydrolysis of Squid Ink Protein (Loligo Sp) With Papain Enzyme. fishtech. Fishery Products Technology Study Program, Sriwijaya University. Volume 1, Number 1.

Putri, D.S. 215. Effect of replacing natural diet with artificial diet on the survival and growth of star pomfret (Tracinotus blochii, Lacepede) larvae. Hasanuddin University Thesis.

Rimandi, O. 2015. Developmental Response of Crayfish (Portunus pelagicus) Larvae to Accelerated Change of Natural Diet to Artificial Diet Predigest With Probiotic Bacillus sp. Thesis. Hasanuddin University Graduate School. Makassar.

Taqwdasbriliani, E.G., Johannes, H and Endang, A. 2013. Effect of Combination of Papain and Bromelain Enzymes on Diet Utilization and Growth of Tiger Grouper (Epinephelus fuscogutattus). Journal of Aquaculture Management and Technology Volume 2, Number 3, Year 2013, Pages 76-85.

Walford, J and T. J. Lam. 1993. Development of Digestive Tract and Proteolytic Enzyme Activity in Seabass (Lates calcarifer) Larvae and Juveniles. Aqualture, 109(2), 187-205. 